\title{
Metschnikowia hamakuensis sp. nov., Metschnikowia kamakouana sp. nov. and Metschnikowia mauinuiana sp. nov., three endemic yeasts from Hawaiian nitidulid beetles
}

\author{
Marc-André Lachance, ${ }^{1}$ Curtis P. Ewing, ${ }^{2}$ Jane M. Bowles ${ }^{1}$ \\ and William T. Starmer ${ }^{3}$ \\ ${ }^{1}$ Department of Biology, University of Western Ontario, London, Ontario, Canada N6A 5B7 \\ ${ }^{2}$ Department of Entomology, Cornell University, Ithaca, NY 14853, USA \\ ${ }^{3}$ Department of Biology, Syracuse University, Syracuse, NY 13244, USA
}

\begin{abstract}
Three heterothallic, haplontic yeast species, Metschnikowia hamakuensis, Metschnikowia kamakouana and Metschnikowia mauinuiana, are described from isolates associated with endemic nitidulid beetles living on various endemic plants on three Hawaiian islands. As morphospecies, they are similar to Metschnikowia hawaiiensis, but based on mating compatibility and ascospore formation, they can be assigned clearly to distinct biological species. Analysis of ITS/5.8S and D1/D2 large subunit rDNA sequences shows that, with M. hawaiiensis and two other isolates, these species form a distinct subclade within the large-spored Metschnikowia species, indicating that they are Hawaiian endemics. Type cultures are: M. hamakuensis, UWOPS 04-207. $1^{\top}=$ CBS $10056^{\top}=$ NRRL Y-27834 ${ }^{\top}\left(\right.$ type, $\left.\mathrm{h}^{+}\right)$and UWOPS 04-204.1 =CBS $10055=$ NRRL Y-27833 (allotype, $\left.h^{-}\right) ; M$. kamakouana, UWOPS 04-112.5 ${ }^{\top}=$ CBS $10058^{\top}=$ NRRL $\mathrm{Y}-27836^{\top}\left(\right.$ type, $\left.\mathrm{h}^{+}\right)$and UWOPS 04-109.1 $=$CBS $10057=\mathrm{NRRL} \mathrm{Y}-27835$ (allotype, $\mathrm{h}^{-}$); and M. mauinuiana, UWOPS $04-190.1^{\top}=\mathrm{CBS} 10060^{\top}=\mathrm{NRRL} Y-27838^{\top}$ (type, $\mathrm{h}^{+}$) and UWOPS 04-110.4 =CBS 10059=NRRL Y-27837 (allotype, $\mathrm{h}^{-}$).
\end{abstract}

\section{INTRODUCTION}

Metschnikowia and related species associated with nitidulid beetles have been discovered at an accelerating pace since the description of the first member of the large-spored group, 15 years ago (Lachance et al., 1990, 1998a, b, 2001a, 2003a). Recently, Lachance et al. (2003b) suggested that it may be possible to recognize, among Hawaiian members of the group, some that were introduced through human activity (Metschnikowia lochheadii and Candida ipomoeae) and others that may be endemic to Hawai'i (Metschnikowia hawaiiensis and Candida kipukae). In the first instance, the yeasts are associated with a Central American beetle species and adapted to warm temperatures, which would account in part for their occurrence in lowland habitats across the Hawaiian archipelago (Lachance et al., 2001a, 2003b). Showing conclusively that a yeast species occurs only in Hawai' $i$ would be difficult and so the demonstration of endemism requires a different approach. For example, the observation

Published online ahead of print on 14 January 2005 as DOI 10.1099/ ijs.0.63615-0.

The GenBank/EMBL/DDBJ accession numbers for the ITS/5.8S and D1/D2 LSU rDNA sequences of the novel isolates identified in this study are shown in Fig. 2. that $M$. hawaiiensis is associated with a beetle that is endemic to the island of Hawai'i would support the view that the yeast itself has speciated in that region. It happens that the beetle reported as 'nitidulid B' by Lachance et al. (2003b) has now been identified as Prosopeus subaeneus, which is indeed a Hawaiian endemic (Ewing, 2004). Further evidence that the yeast is not an introduced exotic would arise from the isolation of a sister species of $M$. hawaiiensis in a similar Hawaiian habitat. In June 2004, we sampled several species of endemic nitidulids found on native plants in various nature reserves on the islands of Moloka'i, Maui and Hawai'i. Many of the isolates represented novel species, including five sister species to $M$. hawaiiensis. Three of these were represented by multiple strains and included both mating types; we now describe them as Metschnikowia hamakuensis sp. nov., Metschnikowia kamakouana sp. nov. and Metschnikowia mauinuiana sp. nov.

\section{METHODS}

Collections. The collection sites relevant to this study (Table 1) were the following Hawaiian rainforest localities: Kamakou Preserve area $\left(21^{\circ} 8^{\prime} \mathrm{N} 156^{\circ} 55^{\prime} \mathrm{W}, 1200 \mathrm{~m}\right)$, Moloka'i; Waikamoi Preserve area $\left(2048^{\prime} \mathrm{N} 156^{\circ} 15^{\prime} \mathrm{W}, 1300 \mathrm{~m}\right)$, Maui; upper Hamakua ditch $\left(20^{\circ} 5^{\prime} \mathrm{N} 155^{\circ} 41^{\prime} \mathrm{W}, 1200 \mathrm{~m}\right)$, Hawai'i; Pu'u Pala and Pu'u 
Table 1. Origin of yeast isolates considered in this study

Strain numbers refer to the University of Western Ontario (UWOPS) collection. A, Allotype strain; T, type strain.

\begin{tabular}{|c|c|c|c|c|}
\hline \multirow[t]{2}{*}{ Strain } & \multirow[t]{2}{*}{ Mating type } & \multicolumn{3}{|c|}{ Source of isolation } \\
\hline & & Insect species & Plant species & Locality \\
\hline 04-199.1 & $\mathrm{h}^{-}$ & Prosopeus cf. bidens $\mathrm{O}^{\prime}$ & Ilex anomala & Upper Hamakua ditch, Hawai'i \\
\hline $04-201.2^{*}$ & $\mathrm{~h}^{-}$ & Prosopeus cf. bidens or & Ilex anomala & Upper Hamakua ditch, Hawai'i \\
\hline $04-202.1 \dagger$ & $\mathrm{h}^{+}$ & Prosopeus cf. bidens $९$ & Broussaisia arguta & Upper Hamakua ditch, Hawai'i \\
\hline $04-206.3$ & $\mathrm{~h}^{-}$ & Prosopeus cf. bidens o & Ilex anomala & Upper Hamakua ditch, Hawai'i \\
\hline $04-207.1^{\mathrm{T}}$ & $\mathrm{h}^{+}$ & Prosopeus cf. bidens $\bigcirc$ & Broussaisia arguta & Upper Hamakua ditch, Hawai'i \\
\hline $04-215.1$ & $\mathrm{~h}^{+}$ & Prosopeus cf. bidens 우 & Clermontia calophylla & Upper Hamakua ditch, Hawai'i \\
\hline $04-216.2$ & $\mathrm{~h}^{-}$ & Prosopeus cf. bidens 우 & Clermontia calophylla & Upper Hamakua ditch, Hawai'i \\
\hline \multicolumn{5}{|c|}{ M. kamakouana } \\
\hline $04-121.1 \dagger$ & $\mathrm{h}^{+}$ & Prosopeus collaris & Clermontia kakeana & Kamakou Mountain, Moloka’i \\
\hline 04-206.1 & $\mathrm{h}^{-}$ & Prosopeus cf. bidens $\mathrm{O}^{\prime}$ & Ilex anomala & Upper Hamakua ditch, Hawai'i \\
\hline 04-208.1 & $\mathrm{h}^{-}$ & Prosopeus cf. bidens o’ & Broussaisia arguta & Upper Hamakua ditch, Hawai'i \\
\hline $04-217.1 \dagger$ & $\mathrm{h}^{-}$ & Drosophila sp. (larva) & Clermontia calophylla & Upper Hamakua ditch, Hawai'i \\
\hline \multicolumn{5}{|c|}{ M. mauinuiana } \\
\hline $04-107.4 \dagger$ & $\mathrm{h}^{+}$ & Prosopeus collaris & Clermontia kakeana & Kamakou Mountain, Moloka’i \\
\hline $04-110.4^{\mathrm{A}} \dagger$ & $\mathrm{h}^{-}$ & Prosopeus collaris & Clermontia kakeana & Kamakou Mountain, Moloka’i \\
\hline $04-190.1^{T_{*}}$ & $\mathrm{~h}^{+}$ & Prosopeus abnormalis o & Clermontia arborescens & Waikamoi Preserve, Maui \\
\hline \multicolumn{5}{|c|}{ Unassigned isolates } \\
\hline $04-218.3^{\star}$ & $\mathrm{h}^{+}$ & Prosopeus varius & Clermontia kohalae $\ddagger$ & Pu’u Pala, Kohala, Hawai'i \\
\hline $04-226.1^{\star}$ & $\mathrm{h}^{-}$ & Prosopeus sp. & Hedyotis terminalis & Pu’u Pili, Kohala, Hawai'i \\
\hline
\end{tabular}

${ }^{\star} \mathrm{ITS} / 5 \cdot 8 \mathrm{~S}$ and D1/D2 sequences deposited in GenBank (see Fig. 2).

$\dagger \mathrm{ITS} / 5 \cdot 8 \mathrm{~S}$ and D1/D2 sequences determined.

‡The plant material was a fermenting stem and not a flower.

Pili $\left(20^{\circ} 7^{\prime} \mathrm{N} 155^{\circ} 46^{\prime} \mathrm{W}, 1400 \mathrm{~m}\right)$, Kohala Mountain, island of Hawai'i. The plants were identified morphologically as Broussaisia arguta (endemic genus, Hydrangeaceae), Hedyotis terminalis (endemic species, Rubiaceae), Ilex anomala (indigenous species, Aquifoliaceae) and various Clermontia species (endemic genus, Campanulaceae), using the keys of Wagner et al. (1990). Insects were collected aseptically as follows. Broussaisia, Hedyotis or Ilex inflorescences were wrapped in sterile plastic bags and shaken; individual insects were then transferred aseptically to smaller, sterile WhirlPaks. The opening of the large, fleshy Clermontia flowers was placed in a WhirlPak and the corolla was rolled between the fingers to induce release of the usually single beetle; alternatively, the whole flower was collected. With the exception of one Drosophila larva, all insects that yielded yeasts of interest belonged to the Hawaiian endemic genus Prosopeus (Coleoptera: Nitidulidae). Other beetles recovered from flowers in the same collection sites belonged to the related genus Eupetinus. Beetles were identified morphologically by comparison with the type series. The affinities among morphospecies have been corroborated to a large extent by sequencing of the $\mathrm{CO} 1$ mitochondrial gene (C. P. Ewing, unpublished).

Strain isolation. Yeast cultures were obtained by allowing each insect to walk sequentially on the surface of two YM agar plates (glucose $1 \%$, peptone $0.5 \%$, malt extract $0.3 \%$, yeast extract $0 \cdot 3 \%$, agar $2 \cdot 0 \%$, supplemented with $50 \mathrm{mg}$ chloramphenicol $\mathrm{l}^{-1}$ ). One plate was supplemented with $10 \mathrm{mg} N$-hexadecyl- $N, N, N$-trimethylammonium bromide (CTAB) $1^{-1}$, which has been found empirically to select in favour of Metschnikowia species. The insects were removed after 5-10 min contact and the plates were streaked with a sterile loop to spread deposited cells. The plates were examined daily and representative colonies were transferred to small YM agar slopes. Upon return to the laboratory, the cultures were purified by suspending in sterile water and streak-inoculating onto YM agar free of antimicrobials. Selected cultures were stored in liquid nitrogen.

Yeast systematics. Delineation and identification of heterothallic, haplontic Metschnikowia species were based primarily on mating reactions. Active cultures were mixed in pairs on yeast carbon base (Difco) supplemented with $0.01 \%$ ammonium sulphate, incubated at $18{ }^{\circ} \mathrm{C}$ and examined periodically for the formation of zygotes, asci or ascospores. Authentic strains of previously described species were included in experiments as appropriate. Any questionable identification was verified by rDNA sequencing and then reconfirmed by mating. The internal transcribed spacers, the $5 \cdot 8 \mathrm{~S}$ gene and the D1/ D2 variable domains of the large subunit were amplified directly from whole cells with primers IT1 and NL4 as described previously (Marinoni \& Lachance, 2004). The PCR products were sequenced at the Robarts Research Institute (London, Ontario, Canada). Sequence 


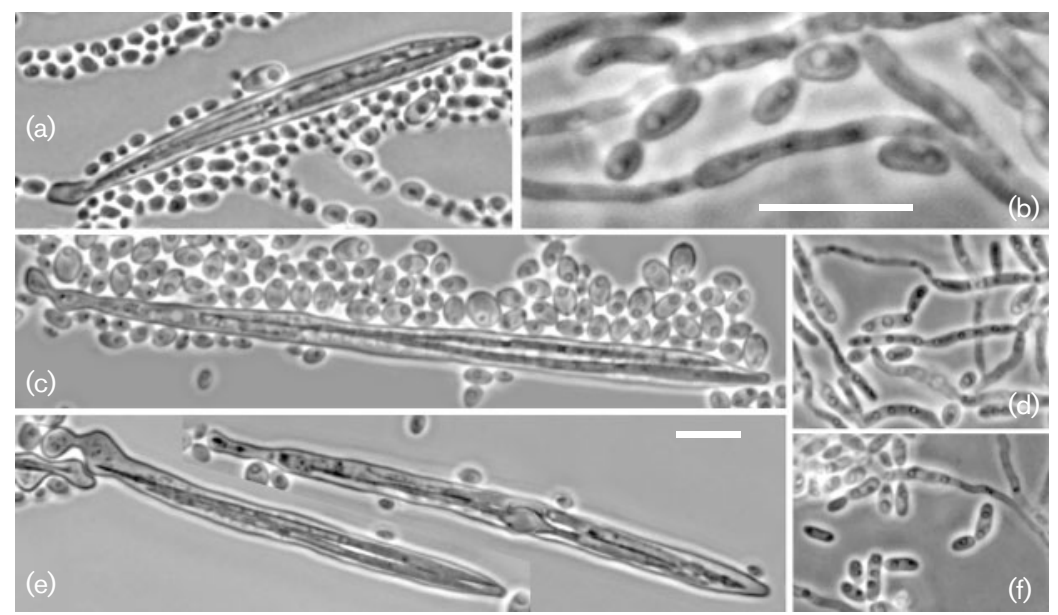

Fig. 1. Phase-contrast micrographs of Metschnikowia hamakuensis (a, b), Metschnikowia kamakouana (c, d) and Metschnikowia mauinuiana (e, f). Asci of mixed types and allotypes after 3 days ( $\mathrm{a}, \mathrm{c}, \mathrm{e})$; pseudohyphae and vegetative cells $(b, d, f)$; yeast carbon base, $0.01 \%$ ammonium sulphate agar. Bars, $10 \mu \mathrm{m}$; the bar shown in (e) applies to all panels except (b).

alignment was performed with the integrated software package DNAMAN (Lynnon Biosoft). Tree construction was based on the program DNAPARS of the PHYLIP package (version 3.6; J. Felsenstein). Morphological and physiological characterization followed the methods of Yarrow (1998).

\section{RESULTS AND DISCUSSION}

\section{Latin diagnosis of Metschnikowia hamakuensis Lachance sp. nov.}

In medio YM post dies tres cellulae singulae, binae, aut in catenis brevis, globosae aut ovoidae $(2-4 \times 3-6 \mu \mathrm{m})$, aliquando cum tubis longibus. Cultura in agaro malti post dies 14 infimo-convexa, glabra, candida et butyrosa aut coriacea. In agaro carbonis fundamento post dies 14 pseudomycelium formatur. Post dies unus, cellulae stirpum interfertilium mixtarum in agaro carbonis fundamento tubi junctionis formantur. Post dies tres, magni asci cylindrati possunt videri. Asci stabiles sunt. Ascosporae aculeatae (1.3-1.6 $\times 40-60 \mu \mathrm{m})$. Glucosum et trehalosum (lente et exigue) fermentantur. Glucosum, sucrosum, galactosum, trehalosum, maltosum, melezitosum, cellobiosum, salicinum, L-sorbosum, D-xylosum, ethanolum (lente), glycerolum (lente), ribitolum, xylitolum, mannitolum, glucitolum, acidum succinicum, acidum citricum, glucono- $\Delta$-lactonum, acidum gluconicum, 2-ketogluconatum, $N$-acetylglucosaminum, ethyl acetas (lente) et hexadecanum, at non inulinum, raffinosum, melibiosum, lactosum, methyl- $\alpha-\mathrm{D}-$ glucosidum, amylum solubile, L-rhamnosum, L-arabinosum, D-arabinosum, Dribosum (aliquando exigue aut lente), methanolum, 1propanolum, 2-propanolum, 1-butanolum, erythritolum, galactitolum, meso-inositolum, acidum lacticum, glucosaminum (aliquando lente) nec acetonum. Ethylaminum, lysinum et cadaverinum assimilantur at non natrium nitricum nec natrium nitrosum. Ad crescentiam vitaminae externae necessariae sunt. Augmentum in $27^{\circ} \mathrm{C}$, at non $29^{\circ} \mathrm{C}$.

Habitat Prosopeus cf. bidens e floribus variebus in Hawaii. Typus UWOPS 04-207.1 $\left(\mathrm{h}^{+}\right)$. Allotypus UWOPS 04204.1. In collectione zymotica Centraalbureau voor
Schimmelcultures, Trajectum ad Rhenum, sub no. CBS $10056^{\mathrm{T}}$ et CBS 10055 depositae sunt.

\section{Description of Metschnikowia hamakuensis Lachance sp. nov.}

Metschnikowia hamakuensis (ha.ma.ku.en'sis. L. nom. sing. f. adj. hamakuensis of Hamakua, referring to the Upper Hamakua ditch, Kohala Mountain, Hawai'i, where all known strains of this species were recovered).

On YM agar after 3 days at $25^{\circ} \mathrm{C}$, cells are spherical to ovoidal, occur singly, in parent-bud pairs or in short chains, and measure $2-4 \times 3-6 \mu \mathrm{m}$. Highly refringent cells, as well as very long germ tubes, can be observed on occasion. After 2 weeks, colonies are low-convex to convex, glossy, white, small to medium, and butyrous or leathery due to intertwined tubes. In Dalmau plate culture on yeast carbon base agar after 2 weeks, pseudohyphae are formed (Fig. 1b). On yeast carbon base agar at $18{ }^{\circ} \mathrm{C}$, mixtures of cells of complementary mating types give rise to zygotes and asci after 6-12 h. After 3 days, mature asci containing two acicular ascospores $(1.3-1.6 \times 40-60 \mu \mathrm{m})$ are formed in a persistent ascus that retains more or less conspicuous vestiges of the conjugated parent cells (Fig. 1a). Fermentation: in glucose, gas production begins after 3-4 days and a full tube of gas develops after 10 days. In some strains fermentation is delayed and much weaker. Of other assimilated sugars, only trehalose is fermented weakly in some strains. Other growth test responses are given in Table 2.

The habitat is in Prosopeus cf. bidens (Coleoptera: Nitidulidae) associated with flowers of Ilex anomala, Broussaisia arguta and Clermontia calophylla growing along the upper Hamakua ditch, Kohala Mountain, island of Hawai'i.

The type strain of $M$. hamakuensis is strain UWOPS 04207.1 $\mathrm{T}^{\mathrm{T}}\left(\mathrm{h}^{+}\right)$, recovered from Prosopeus cf. bidens on flowers of Broussaisia arguta. The designated allotype is strain UWOPS 04-204.1 $\left(\mathrm{h}^{-}\right)$, recovered from Prosopeus cf. bidens on flowers of Ilex anomala. The type locality is 
Table 2. Comparison of growth characteristics that vary among $M$. kamakouana, M. mauinuiana, M. hamakuensis, Metschnikowia spp. 04-218.3 and 04-226.1 and M. hawaiiensis

Species are abbreviated as: kam, M. kamakouana; mau, M. mauinuiana; ham, M. hamakuensis; haw, M. hawaiiensis. All strains gave positive responses for the assimilation of glucose, sucrose, galactose, trehalose, maltose, melezitose, L-sorbose, D-xylose, mannitol, glucitol, succinic acid, citric acid, glucono- $\Delta$-lactone (slow), 2-ketogluconate, $\mathrm{N}$-acetylglucosamine and hexadecane (carbon sources), ethylamine, L-lysine and cadaverine (nitrogen sources), growth in the absence of amino acids, growth at $25^{\circ} \mathrm{C}$, and growth in the presence of $10 \% \mathrm{NaCl}$ and $20 \mathrm{mg}$ $\mathrm{CTAB} 1^{-1}$. All strains gave negative responses for the assimilation of inulin, raffinose, melibiose, lactose, starch, L-rhamnose, L-arabinose, Darabinose, methanol, 1-propanol, 2-propanol, 1-butanol, erythritol, galactitol, inositol, DL-lactic acid, glucuronic acid and acetone (carbon sources), nitrate and nitrite (nitrogen sources), growth in the absence of vitamins, hydrolysis of gelatin and casein, growth in the presence of $0.001 \%$ cycloheximide, starch production, the diazonium blue B reaction and growth in the presence of acetic acid. Responses are shown as: -, negative; $\mathrm{W}$, weak; $\mathrm{V}$, variable; $\mathrm{s}$, slow; +, positive.

\begin{tabular}{|c|c|c|c|c|c|c|}
\hline Growth test & $04-218.3$ & $04-226.1$ & kam & mau & ham & haw \\
\hline \multicolumn{7}{|l|}{ Assimilation of: } \\
\hline Methyl $\alpha$-D-glucoside & - & - & $\mathrm{W}$ & - & - & - \\
\hline Cellobiose & + & - & + & + & + & + \\
\hline Salicin & + & - & + & + & + & + \\
\hline D-Ribose & $\mathrm{W}$ & $\mathrm{W}$ & - & $-/ \mathrm{w} / \mathrm{s}$ & $-/ \mathrm{w} / \mathrm{s}$ & - \\
\hline Ethanol & $\mathrm{W}$ & $S$ & s & S & S & + \\
\hline Glycerol & $\mathrm{W}$ & $\mathrm{W}$ & $\mathrm{W} / \mathrm{s}$ & + & S & + \\
\hline Ribitol & S & $\mathrm{W}$ & $-/ \mathrm{w} / \mathrm{s}$ & S & + & W \\
\hline Xylitol & s & + & W & + & + & s \\
\hline Gluconic acid & - & + & $\mathrm{W} / \mathrm{s}$ & $\mathrm{w} / \mathrm{s} /+$ & + & $\mathrm{W}$ \\
\hline Glucosamine & - & $\mathrm{w}$ & $-/ \mathrm{w}$ & $\mathrm{w} / \mathrm{s}$ & $-/ \mathrm{s}$ & $-/ \mathrm{s}$ \\
\hline Ethyl acetate & $\mathrm{W}$ & s & $-/ \mathrm{W}$ & $\mathrm{W}$ & S & S \\
\hline Growth at $4{ }^{\circ} \mathrm{C}$ & $\mathrm{W}$ & $\mathrm{W}$ & $\mathrm{W}$ & $\mathrm{W}$ & $\mathrm{W}$ & - \\
\hline Maximum growth temperature $\left({ }^{\circ} \mathrm{C}\right)$ & 26 & 27 & 28 & 28 & $27-28$ & $32-33$ \\
\hline Tween 80 hydrolysis & + & - & $\mathrm{V}$ & - & - & $-/ \mathrm{w}$ \\
\hline Acid production & - & - & $\mathrm{V}$ & - & - & - \\
\hline \multicolumn{7}{|l|}{ Growth in the presence of: } \\
\hline $\mathrm{NaCl}(15 \%)$ & S & - & $\mathrm{w} / \mathrm{s}$ & S & S & S \\
\hline Glucose $(50 \%)$ & - & - & - & $\mathrm{w} / \mathrm{s}$ & $-/ \mathrm{w}$ & s \\
\hline CTAB (50 mg $\left.\mathrm{l}^{-1}\right)$ & - & + & + & $-/ \mathrm{w} /+$ & W & + \\
\hline
\end{tabular}

the upper Hamakua ditch, Kohala Mountain, Hawai'i. These strains have been deposited in the collection of the Yeast Division of the Centraalbureau voor Schimmelcultures, Utrecht, the Netherlands, as strains CBS $10056^{\mathrm{T}}$ (=NRRL Y-27834 ${ }^{\mathrm{T}}$ ) and CBS 10055 (=NRRL Y-27833), respectively.

\section{Latin diagnosis of Metschnikowia kamakouana Lachance sp. nov.}

In medio YM post dies tres cellulae singulae, binae, aut in catenis brevis, globosae aut ovoidae $(2-4 \times 3-6 \mu \mathrm{m})$, aliquando cum tubis longibus. Cultura in agaro malti post dies 14 infimo-convexa, tumulosa, glabra, candida et butyrosa. In agaro carbonis fundamento post dies 14 pseudomycelium formatur. Post dies unus, cellulae stirpum interfertilium mixtarum in agaro carbonis fundamento tubi junctionis formantur. Post dies tres, magni asci cylindrati possunt videri. Asci stabiles sunt. Ascosporae aculeatae $(1 \cdot 0-1 \cdot 7$ $\times 90-110 \mu \mathrm{m})$. Glucosum et trehalosum (exigue et variabile) fermentantur. Glucosum, sucrosum, galactosum, trehalosum, maltosum, melezitosum, methyl- $\alpha$-D-glucosidum (exigue), cellobiosum, salicinum, L-sorbosum, D-xylosum, ethanolum (lente), glycerolum (exigue aut lente), xylitolum (exigue), mannitolum, glucitolum, acidum succinicum, acidum citricum, glucono- $\Delta$-lactonum, acidum gluconicum (exigue aut lente), 2-ketogluconatum, $N$-acetylglucosaminum, et hexadecanum, at non inulinum, raffinosum, melibiosum, lactosum, amylum solubile, L-rhamnosum, L-arabinosum, D-arabinosum, Dribosum, methanolum, 1-propanolum, 2-propanolum, 1butanolum, erythritolum, galactitolum, ribitolum (aliquando exigue aut lente), meso-inositolum, acidum lacticum, glucosaminum (aliquando exigue), ethyl acetas (aliquando exigue) nec acetonum. Ethylaminum, lysinum et cadaverinum assimilantur at non natrium nitricum nec natrium nitrosum. Ad crescentiam vitaminae externae necessariae sunt. Augmentum in $28^{\circ} \mathrm{C}$, at non $29^{\circ} \mathrm{C}$.

Habitat Prosopeus spp. et Drosophila spp. e floribus variebus in Hawaii. Typus UWOPS 04-112.5 ${ }^{\mathrm{T}}\left(\mathrm{h}^{+}\right)$. Allotypus UWOPS 04-109.1. In collectione zymotica Centraalbureau voor Schimmelcultures, Trajectum ad Rhenum, sub no. CBS $10058^{\mathrm{T}}$ et CBS 10057 depositae sunt. 


\section{Description of Metschnikowia kamakouana Lachance sp. nov.}

Metschnikowia kamakouana (ka.ma.kou.a'na. L. nom. sing. f. adj. kamakouana of Kamakou, referring to the Kamakou Mountain rainforest, Moloka'i, where most strains of this species were recovered).

On YM agar after 3 days at $25^{\circ} \mathrm{C}$, cells are spherical to ovoidal, occur singly, in parent-bud pairs or in short chains, and measure $2-4 \times 3-6 \mu \mathrm{m}$. Highly refringent cells can be observed on occasion. After 2 weeks, colonies are lowconvex to convex, umbonate with concentric circles, glossy to semi-glossy, white, medium to large, and butyrous. In Dalmau plate culture on Yeast Carbon Base agar after 2 weeks, pseudohyphae are formed (Fig. 1d). After 3 days, mature asci containing two acicular ascospores $(1 \cdot 0-1 \cdot 7 \times$ $90-110 \mu \mathrm{m})$ are formed in a persistent ascus that retains vestiges of the conjugated parent cells (Fig. 1c). Fermentation: in glucose, gas production begins after 2-3 days and a full tube of gas develops after 5-6 days. Of other assimilated sugars, only trehalose was fermented weakly in some strains. Other growth test responses are given in Table 2.

The habitat is in Prosopeus species (one strain from a Drosophila larva) associated with flowers of Ilex anomala, Broussaisia arguta and Clermontia species growing in the area of the Kamakou Preserve, Moloka'i and along the upper Hamakua ditch, Kohala Mountain, island of Hawai'i.

The type strain of M. kamakouana is strain UWOPS 04$112.5^{\mathrm{T}}\left(=\mathrm{CBS} 10058^{\mathrm{T}}=\right.$ NRRL Y-27836 $\left.{ }^{\mathrm{T}}\right)\left(\mathrm{h}^{+}\right)$, recovered from a specimen of Prosopeus collaris found in a flower of Clermontia kakeana. The designated allotype is strain UWOPS 04-109.1 $\left(=\right.$ CBS 10057 = NRRL Y-27835) $\left(\mathrm{h}^{-}\right)$, recovered from a similar insect-plant combination. The type locality is the area of the Kamakou Preserve, Moloka'i.

\section{Latin diagnosis of Metschnikowia mauinuiana Lachance sp. nov.}

In medio YM post dies tres cellulae singulae, binae, aut in catenis brevis, globosae aut ovoidae $(2-4 \times 3-6 \mu \mathrm{m})$, aliquando cum tubis longibus. Cultura in agaro malti post dies 14 infimo-convexa, tumulosa, glabra, candida et butyrosa. In agaro carbonis fundamento post dies 14 pseudomycelium formatur. Post dies unus, cellulae stirpum interfertilium mixtarum in agaro carbonis fundamento tubi junctionis formantur. Post dies tres, magni asci cylindrati possunt videri. Asci stabiles sunt. Ascosporae aculeatae $(1.2-1.6 \times 70-80 \mu \mathrm{m})$. Glucosum et trehalosum (exigue) fermentantur. Glucosum, sucrosum, galactosum, trehalosum, maltosum, melezitosum, cellobiosum, salicinum, L-sorbosum, D-xylosum, ethanolum (lente), glycerolum, ribitolum (lente), xylitolum, mannitolum, glucitolum, acidum succinicum, acidum citricum, glucono- $\Delta$ lactonum, acidum gluconicum (aliquando exigue aut lente), 2-ketogluconatum, glucosaminum (exigue aut lente), $N$ acetylglucosaminum, ethyl acetas (exigue) et hexadecanum, at non inulinum, raffinosum, melibiosum, lactosum, methyl- $\alpha$-Dglucosidum, amylum solubile, L-rhamnosum, L-arabinosum,
D-arabinosum, D-ribosum (aliquando exigue aut lente), methanolum, 1-propanolum, 2-propanolum, 1-butanolum, erythritolum, galactitolum, meso-inositolum, acidum lacticum (aliquando exigue), nec acetonum. Ethylaminum, lysinum et cadaverinum assimilantur at non natrium nitricum nec natrium nitrosum. Ad crescentiam vitaminae externae necessariae sunt. Augmentum in $28^{\circ} \mathrm{C}$, at non $29^{\circ} \mathrm{C}$.

Habitat Prosopeus spp. et Drosophila spp. e floribus variebus in Hawaii. Typus UWOPS 04-190.1 ${ }^{\mathrm{T}}\left(\mathrm{h}^{+}\right)$. Allotypus UWOPS 04-110.4. In collectione zymotica Centraalbureau voor Schimmelcultures, Trajectum ad Rhenum, sub no. CBS $10060^{\mathrm{T}}$ et CBS 10059 depositae sunt.

\section{Description of Metschnikowia mauinuiana Lachance sp. nov.}

Metschnikowia mauinuiana (ma.u.i.nu.i'a.na. L. nom. sing. f. adj. mauinuiana of Maui Nui, referring to the prehistoric island of Maui Nui, now represented by the separate islands of Moloka'i, Maui, Lana'i and Kahoolawe. The known strains of this species were recovered on the former two islands).

On YM agar after 3 days at $25^{\circ} \mathrm{C}$, cells are spherical to ovoidal, occur singly, in parent-bud pairs or occasionally in clumpy chains, and measure $2-4 \times 3-6 \mu \mathrm{m}$. After 2 weeks, colonies are convex-umbonate to low-convex, glossy to semi-glossy, white, medium to small, and butyrous. In Dalmau plate culture on yeast carbon base agar after 2 weeks, pseudohyphae are formed (Fig. 1f). On yeast carbon base agar at $18{ }^{\circ} \mathrm{C}$, mixtures of cells of complementary mating types give rise to zygotes and asci after 6-12 h. On yeast carbon base agar at $18{ }^{\circ} \mathrm{C}$, mixtures of cells of complementary mating types give rise to zygotes and asci after 6-12 h. After 3 days, mature asci containing two acicular ascospores $(1.2-1.6 \times 70-80 \mu \mathrm{m})$ are formed in a persistent ascus that retains more or less conspicuous vestiges of the conjugated parent cells (Fig. 1e). Some spores may exhibit a central swelling. Fermentation: in glucose, gas production begins after 2-3 days and a full tube of gas develops after 5-6 days. Of other assimilated sugars, only trehalose was fermented weakly. Other growth test responses are given in Table 2.

The habitat is in Prosopeus species associated with flowers of Clermontia species growing in the area of the Kamakou Preserve, Moloka'i and in the area of the Waikamoi Preserve, Maui.

The type strain of M. mauinuiana is strain UWOPS 04$190.1^{\mathrm{T}}\left(=\mathrm{CBS} 10060^{\mathrm{T}}=\right.$ NRRL Y-27838 $\left.8^{\mathrm{T}}\right)\left(\mathrm{h}^{+}\right)$, recovered from a specimen of Prosopeus abnormalis found in a flower of Clermontia arborescens in the area of the Waikamoi Preserve, Maui. The designated allotype is strain UWOPS 04-110.4 (=CBS 10059= NRRL Y-27837) $\left(\mathrm{h}^{-}\right)$, recovered from a specimen of Prosopeus collaris found in a flower of Clermontia kakeana in the area of the Kamakou Preserve, Moloka'i. 


\section{Ecology}

The 68 floricolous insect specimens examined in the localities listed in Table 1 yielded some 200 yeast isolates. Of these, 21 isolates belonged to the large-spored Metschnikowia clade, but none could be assigned to M. hawaiiensis, M. lochheadii, Candida ipomoeae or Candida kipukae. These four species have been isolated repeatedly (Lachance et al., 2003b) from beetles collected on flowers of the morning glory Ipomoea indica, a native but pantropical species, in the vicinity of Kipuka Puaulu, on the southern slope of Mauna Loa volcano, island of Hawai'i. During this study, 87 specimens of Prosopeus subaeneus or Conotelus mexicanus (an introduced nitidulid) collected in that region yielded 77 isolates of C. ipomoeae, 57 of M. hawaiiensis, 36 of M. lochheadii, 20 of C. kipukae and none of the species listed in Table 1. The sharp discontinuity in the distribution of M. hawaiiensis and the sister species described here is noteworthy and may be linked in part to differences in maximum growth temperature (Table 1).

Among other yeasts isolated in the same samples as the new species were several possibly endemic Hanseniaspora species, including some that were recently described by Cadez et al. (2003), the sister pair Candida oleophila and Candida railenensis and a number of undescribed species with affinities to Pichia membranifaciens, to Pichia lachancei (also a putative Hawaiian endemic) and to the smallerspored Metschnikowia subclade. Conspicuous by their absence were members of the Wickerhamiella clade, except for rare isolates of a sister species to Candida azyma. This is in very sharp contrast to the yeast community typically associated with the beetles found in Hawaiian morning glories, where several members of the Wickerhamiella clade are common and are thought to be vectored principally by Drosophila species (Lachance et al., 2001b).

Although exact counts were not made, a superficial correlation was perceived between the cell densities of the novel species and their frequency of recovery. This might be attributed to the short flowering season of the endemic plants compared to the nearly constant blooming of Hawaiian morning glories. Presumably, the overall yeast population increases in size with the abundance of available flowers. Climatic factors may play a role also. In the period preceding our collections, the Kamakou and Hamakua sites had experienced abundant rainfall compared to Waikamoi, Pu'u Pala and Pu'u Pili. More flowers, more beetles and larger yeast populations were found in the first two sites.

\section{Species delineation}

Table 3 shows the results of mating experiments. When mixed in compatible pairs, large-spored Metschnikowia species conjugate and give rise to zygotes within $4-6 \mathrm{~h}$ (Lachance et al., 1998a). The zygotes are usually transformed rapidly into large asci, but the formation of ascospores, when present, is delayed for 2 days $\left(25^{\circ} \mathrm{C}\right)$. In the present case, strains were assigned to the same species only when compatible crosses resulted in the formation of abundant asci that contained pairs of ascospores after 3 days at $18^{\circ} \mathrm{C}$. Incubation for shorter periods or at higher temperatures gave less reliable results and prolonged incubation did not facilitate the detection of ascospores. Included for comparison were strains UWOPS 04-218.3 ( = CBS 10061 = NRRL Y-27839) and UWOPS 04-226.1 $(=$ CBS $10062=$ NRRL Y27840), which represent two different Metschnikowia species whose description is not possible at this time, as only one strain is available for each. The results of crosses between species ranged from no signs of reactivity in some cases, to the formation of abundant but sterile asci in others. In some cases, the asci were sufficiently rare that they might have been overlooked. However, abortive zygotes such as those produced by crosses between Metschnikowia colocasiae and relatives (Lachance \& Bowles, 2004) were not seen. Unlike what has been reported for M. borealis and Metschnikowia continentalis (Lachance et al., 1998a), crosses between the novel species never gave rise to ascospores.

The number of substitutions in the D1/D2 variable domains of the large subunit rDNA is normally a reliable predictor of yeast species boundaries (Kurtzman \& Robnett, 1998). This was the case in the present study but for one minor exception. The sequence-based separation of M. hamakuensis from $M$. hawaiiensis would be tenuous as the two differed by only one substitution and one gap in the D1/D2 region. However, their ITS1 regions differed by five substitutions and three gaps. An ITS1 polymorphism was observed within M. hamakuensis, whereby strain UWOPS 04-201.2 differed from others by two substitutions and a five-position gap, which is why it was included in Fig. 2. Although M. mauinuiana and M. hawaiiensis differed by five substitutions and two gaps in the D1/D2 region, their ITS regions were nearly identical (one gap). These ambiguities explain the lower bootstrap value assigned to the $M$. hamakuensis-M. hawaiiensis pair. Simplistic interpretations of these inconsistencies might be that $M$. hawaiiensis arose as a hybrid between early forms of the other two species, or

Table 3. Mating and ascospore formation among selected large-spored Metschnikowia species

Species are abbreviated as: bor, M. borealis; kam, M. kamakouana; mau, M. mauinuiana; ham, M. hamakuensis; haw, M. hawaiiensis. Results reported as: + , ascospores present; s, sterile asci; -, no mating. Parentheses indicate that very few asci were detected.

\begin{tabular}{|c|c|c|c|c|c|c|}
\hline \multirow[t]{2}{*}{ Mating type $h^{-}$} & \multicolumn{6}{|c|}{ Mating type $h^{+}$} \\
\hline & bor & $04-218.3$ & kam & mau & ham & haw \\
\hline M. borealis & + & $\mathrm{s}$ & S & (s) & - & - \\
\hline $04-226.1$ & $\mathrm{~s}$ & (s) & (s) & - & - & (s) \\
\hline M. kamakouana & $\mathrm{S}$ & $\mathrm{S}$ & + & - & (s) & S \\
\hline M. mauinuiana & (s) & $\mathrm{s}$ & (s) & + & $\mathrm{s}$ & S \\
\hline M. hamakuensis & $(\mathrm{s})$ & (s) & $(\mathrm{s})$ & (s) & + & (s) \\
\hline M. hawaiiensis & $\mathrm{S}$ & S & S & $\mathrm{S}$ & $\mathrm{s}$ & + \\
\hline
\end{tabular}




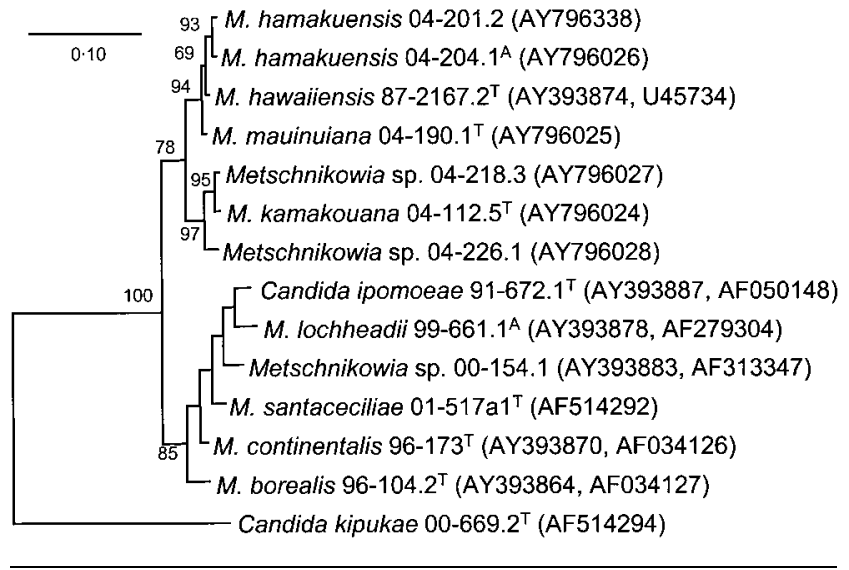

Fig. 2. Phylogram showing the relationships among members of the large-spored Metschnikowia clade discussed in this study, based on ITS/5.8S and D1/D2 LSU rDNA sequences. The parsimony analysis was pseudo-replicated 100 times; only bootstrap values higher than $50 \%$ are shown.

that it represents an intermediate stage between them. Strong evidence in support of either alternative is lacking.

\section{Phylogeny, biogeography, speciation and phenotypic variation}

The novel species form a monophyletic clade with $M$. hawaiiensis and two unassigned isolates based on an analysis of ITS and D1/D2 LSU rDNA sequences (Fig. 2). The generally high bootstrap values obtained within the Hawaiian subclade were unexpected, in view of the minor incongruences outlined above as well at the known instability of the continental subclade (Lachance, 2004). The latter, when analysed through various sequences including those of the complete rDNA operon and the small subunit mitochondrial rDNA, produced different phylogenies independently of the tree construction method. Conflicting phylogenetic signals were identified between different domains of the rDNA cluster. This was tentatively attributed to introgression resulting from the highly conserved mating system found in these species. If the higher topological stability of the Hawaiian clade is due to stronger reproductive isolation among the component species, concordant phylogenies can be expected from multiple sequences.

The diversification of Hawaiian large-spored Metschnikowia species is undoubtedly linked to the isolation that follows from dispersal and subsequent founding events by their vector, the adult beetle. Factors that influence successful long-distance dispersal of the vector are primarily geological (Carlquist, 1974). Successful founding events between islands are likely to be rare and are affected by the timing of island formation and tectonic plate movement. As a new island emerges at the plate junction, the new volcano moves with the plate (north-westerly). As a consequence, the distance between new islands depends on the tempo of volcanic activity and rate of plate movement. New islands do not become receptive to new populations until the elevation, climate and host plant populations are suitable for occupation. Founding events between areas on the same island are influenced by the same factors as those between islands. As volcanoes grow, move and merge to form a new island, the regions between the volcanoes are uninhabitable and effectively isolate the populations into different habitable zones. Even habitable zones on the same volcanic slope can be effectively separated by rivers of larva that leave pockets of vegetation (kippukas) separated from one another. In general, insular conditions (between islands, between volcanoes and between kippukas) are expected to favour a loss of dispersal ability and facilitate isolation of plants and animals.

This cascade of geographical and biotic factors combine to foster peripatric speciation of the yeasts and provide an ideal framework for studying and understanding diversification at a level that is not possible for continental biota. This kind of phenomenon has been documented in Hawai'i, not only for the famous picture-winged Drosophila species (Carson, 1983), but also for other insects, spiders and plants (Coyne \& Orr, 2004). Yeasts can now be added to the list. A plausible account of speciation history would view $M$. hawaiiensis as the most recently derived species, as it is confined to the most volcanically active part of the Hawaiian archipelago and also the youngest [less than 0.4 million years ago (Myr); Clague \& Dalrymple, 1989]. M. hamakuensis is a likely candidate for the progenitor of $M$. hawaiiensis, being exclusive to the Kohala region, dated at $0.43 \mathrm{Myr}$, on the same island. M. mauinuiana would be next in line, given its broader distribution in the Maui Nui geological zone (East Maui, 0.75 Myr; Moloka'i, ca. $1 \cdot 8 \mathrm{Myr})$. The remaining taxa represent more ancestral forms that could have dispersed from older islands. Appropriate exploration of the yeast community of beetles endemic to Oahu and Kauai (5•1 Myr) might reveal whether other vestigial species exist and make it possible to generate a reasonable estimate of the age of the Hawaiian clade.

More elaborate hypotheses on the putative genesis of these species would be very speculative. However, this is a rare occasion where it is appropriate to see whether certain properties of yeast species can be assigned a polarity in evolutionary time. Wickerham (1951), in his pioneering essay on the genus Hansenula, attempted such an exercise. He arranged the various species along 'lines of development', from primitive, haploid, plant-dependent and nutritionally specialized states, to advanced, diploid, freeliving and nutritionally diversified states. The concept was extended to Kluyveromyces species by van der Walt (1970) and later by Kock et al. (1988). However, these models have not stood the test of time, as the proposed relationships amongst Hansenula or Kluyveromyces species were not validated by sequence-based measurements of genetic relatedness (Kurtzman \& Robnett, 1998). Here, temporal polarity could be assigned to traits for which a gradient can be identified across species as a function of their 
evolutionary distance from M. hawaiiensis. As is the case for most Metschnikowia species, the novel species are physiologically homogeneous. In spite of this, characters that show some sort of a gradient included (Table 2) the utilization of methyl $\alpha$-D-glucoside, ethanol and glycerol, as well as growth in the presence of $50 \%$ glucose or $15 \% \mathrm{NaCl}$. For most of these, the presumed ancestral state is shared with most members of the sister clade of large-spored species found on the American continent. Maximum growth temperatures do not fit well in that scheme. Although a gradient from 26 to $33^{\circ} \mathrm{C}$ is apparent along the Hawaiian species, the highest values would have been expected for the more ancestral species, given the $35-37^{\circ} \mathrm{C}$ observed among the continental species. As little is known on the plasticity of maximum growth temperatures in these yeasts, the subject is clearly worthy of more detailed exploration.

Strong support for peripatric speciation came from the gradient observed at the level of interfertility. An interesting mating asymmetry has been reported (Lachance et al., 1998a; Marinoni \& Lachance, 2004), whereby crosses between $M$. hawaiiensis and the continental clade members give rise to some asci, but only when the $\mathrm{h}^{-}$of $M$. hawaiiensis is mixed with a continental $\mathrm{h}^{+}$partner. The reciprocal cross is unreactive, suggesting the existence of incompatibilities between the $\mathrm{h}^{+}$pheromone and the $\mathrm{h}^{-}$ receptor site. If the Hawaiian species arose in succession, one would expect the most derived species to be fully compatible with $M$. hawaiiensis and the most ancestral species to mate freely with the continental species. In Table 3, the continental subclade is represented by $M$. borealis although any member would do. Consistent with its proximity to $M$. hawaiiensis, M. hamakuensis also mated asymmetrically with M. borealis. M. mauinuiana also exhibited some asymmetry, but rare asci were seen in some crosses with $M$. borealis. As predicted by the peripatry model, conjugation occurred between both mating types of $M$. borealis and the more distant sisters of $M$. hawaiiensis, as well as between $M$. hawaiiensis and its closest relatives.

Ascus size, however, did not follow the same gradient. $M$. hawaiiensis forms the largest asci (up to $250 \mu \mathrm{m}$; Lachance et al., 1990) and its closest relative, M. hamakuensis, the smallest (Fig. 1a). Asci formed by the continental species have an intermediate size (Lachance et al., 1998a, 2001a, 2003a), comparable to those of M. kamakouana (Fig. 1c).

\section{Is everything everywhere?}

'A simple implication of our findings is that those who are interested in microbes need not travel to exotic places to find interesting creatures to study: Most micro-organisms can be found at the local seashore or lake - or, for that matter, in a garden pond.'

This quote from Fenchel \& Finlay (2004) epitomises a pervasive but misleading model of microbial ecology that pictures the microbiosphere as a large Brownian soup containing a relatively small number of highly diffusible species, each ready to fill the next available niche. The ubiquitous dispersal model challenges the very existence of biogeography as a meaningful concept in microbiology. Proponents of ubiquity can be criticised, however, for an excessive reliance on the morphospecies as the unit of diversity, a tendency to extrapolate from 'free-living' protozoa to all micro-organisms, and an anecdotal approach to assessing the relative importance of cosmopolitan versus endemic species. Here, a morphological species concept would underestimate the true number of evolutionarily significant units (biological species) by an order of magnitude. For the most part, the large-spored Metschnikowia species cannot be identified with any confidence except by their mating reactions or their DNA sequences. The diversity of these species can be explained to a great extent by historical and geographical factors. And none of these species is cosmopolitan in distribution. Our claims, however, will remain just as anecdotal as those of the ubiquity model until a systematic and reliable assessment of endemism is available for many more yeast species. Secondly, our conclusions are at present diminished by that fact that we do not yet understand the true nature of the interaction between Metschnikowia species and their vector insects. In the future, we shall attempt to elucidate both issues.

\section{ACKNOWLEDGEMENTS}

This work was funded by the Natural Science and Engineering Research Council of Canada (M.-A.L.) and a travel grant from the Grace H. Griswold Fund, Department of Entomology, Cornell University (C.P.E.). We thank the Department of Lands and Resources of Hawai'i, the Nature Conservancy of Hawai'i (Molokai and Maui sections), the Haleakala Ranch Company, the Kahua Ranch, Hawai'i Volcanoes National Park, the Maui Land and Pineapple Company, P. Petro, P. Hodges and P. Castanera for issuance of permits or authorization to enter their lands. Special thanks are extended to R. Bartlett and K. Magnacca for their generous assistance, as well as T. Lau, B. Gagné, T. Teunison, J. Richards and L. Pratt for their enthusiastic support.

\section{REFERENCES}

Cadez, N., Poot, G. A., Raspor, P. \& Smith, M. T. (2003). Hanseniaspora meyeri sp. nov., Hanseniaspora clermontiae sp. nov., Hanseniaspora lachancei sp. nov. and Hanseniaspora opuntiae sp. nov., novel apiculate yeast species. Int J Syst Evol Microbiol 53, 1671-1680.

Carlquist, S. J. (1974). Island Biology. New York: Columbia University Press.

Carson, H. L. (1983). Chromosomal sequences and interisland colonizations in Hawaiian Drosophila. Genetics 103, 465-482.

Clague, D. A. \& Dalrymple, G. B. (1989). Tectonics, geochronology and origin of the Hawaiian-Emperor volcanic chain. In The Geology of North America, vol. N, The Eastern Pacific Ocean and Hawaii, pp. 188-217. Boulder, CO: Geological Society of America.

Coyne, J. A. \& Orr, H. A. (2004). Speciation. Sunderland, MA: Sinauer.

Ewing, C. P. (2004). Identity of Prosopeus subaeneus Murray and Nesopetinus scottianus Sharp 1908 and parphyly of Nesopeplus Sharp and Nesopetinus Sharp (Coleoptera: Nitidulidae). Bishop Mus Occas Pap 79, 33-45. 
Fenchel, T. \& Finlay, B. J. (2004). The ubiquity of small species: patterns of local and global diversity. Bioscience 54, 777-784.

Kock, J. L. F., Coetzee, D. J. \& Pretoorius, G. H. J. (1988). The phylogenetic development of species representing the genus Kluyveromyces. Syst Appl Microbiol 10, 293-296.

Kurtzman, C. P. \& Robnett, C. J. (1998). Identification and phylogeny of ascomycetous yeasts from analysis of nuclear large subunit (26S) ribosomal DNA partial sequences. Antonie van Leeuwenhoek 73, 331-371.

Lachance, M. A. (2004). Recent developments in the systematics and evolution of yeasts in the large-spored Metschnikowia clade. In Abstracts, 11th International Congress on Yeasts, p. 28. August 2004, Rio de Janeiro, Brazil.

Lachance, M. A. \& Bowles, J. M. (2004). Metschnikowia similis sp. nov. and Metschnikowia colocasiae sp. nov., two ascomycetous yeasts isolated from Conotelus spp. (Coleoptera: Nitidulidae) in Costa Rica. Stud Mycol 50, 69-76.

Lachance, M. A., Starmer, W. T. \& Phaff, H. J. (1990). Metschnikowia hawaiiensis sp. nov., a heterothallic haploid yeast from Hawaiian morning glory and associated drosophilids. Int J Syst Bacteriol 40, 415-420.

Lachance, M. A., Rosa, C. A., Starmer, W. T., Schlag-Edler, B., Barker, J. S. F. \& Bowles, J. M. (1998a). Metschnikowia continentalis var. borealis, Metschnikowia continentalis var. continentalis, and Metschnikowia hibisci, new heterothallic haploid yeasts from ephemeral flowers and associated insects. Can J Microbiol 44, 279-288.

Lachance, M. A., Rosa, C. A., Starmer, W. T. \& Bowles, J. M. (1998b). Candida ipomoeae, a new yeast species related to large-spored Metschnikowia species. Can J Microbiol 44, 718-722.
Lachance, M. A., Bowles, J. M., Kwon, S., Marinoni, G., Starmer, W. T. \& Janzen, D. H. (2001a). Metschnikowia lochheadii and Metschnikowia drosophilae, two new yeast species isolated from insects associated with flowers. Can J Microbiol 47, 103-109.

Lachance, M. A., Starmer, W. T., Rosa, C. A., Bowles, J. M., Barker, J. S. F. \& Janzen, D. H. (2001b). Biogeography of the yeasts of ephemeral flowers and their insects. FEMS Yeast Res 1, 1-8.

Lachance, M. A., Bowles, J. M. \& Starmer, W. T. (2003a). Metschnikowia santaceciliae, Candida hawaiiana, and Candida kipukae, three new yeast species associated with insects of tropical morning glory. FEMS Yeast Res 3, 97-103.

Lachance, M. A., Bowles, J. M. \& Starmer, W. T. (2003b). Geography and niche occupancy as determinants of yeast biodiversity: the yeastinsect - morning glory ecosystem of Kippuka Puaulu, Hawai'i. FEMS Yeast Res 4, 105-111.

Marinoni, G. \& Lachance, M. A. (2004). Speciation in the large-spored Metschnikowia clade and establishment of a new species, Metschnikowia borealis comb. nov. FEMS Yeast Res 4, 587-596.

van der Walt, J. P. (1970). Kluyveromyces (van der Walt) emend. van der Walt. In The Yeasts, a Taxonomic Study, 2nd edn, pp. 316-318. Edited by J. Lodder. Amsterdam: North Holland.

Wagner, W. L., Herbst, D. R., Sohmer, S. H. \& Wilson-Ramsey, Y. (1990). Manual of the Flowering Plants of Hawai'i. Honolulu: University of Hawaii Press.

Wickerham, L. J. (1951). Taxonomy of Yeasts. USDA Technical Bulletin no. 1029. Washington, DC: US Department of Agriculture.

Yarrow, D. (1998). Methods for the isolation and identification of yeasts. In The Yeasts, a Taxonomic Study, 4th edn, pp. 77-100. Edited by C. P. Kurtzman \& J. W. Fell. Amsterdam: Elsevier. 